\title{
Isolation of seaweed-associated bacteria and their morphogenesis-inducing capability in axenic cultures of the green alga UIva fasciata
}

\author{
Ravindra Pal Singh, Vaibhav A. Mantri, C. R. K. Reddy*, Bhavanath Jha \\ Discipline of Marine Biotechnology and Ecology, Central Salt and Marine Chemicals Research Institute, \\ Council of Scientific and Industrial Research (CSIR), Bhavnagar 364021, India
}

\begin{abstract}
In the marine environment, the bacteria that colonize the surface of a seaweed affect its growth and development. In the laboratory, several seaweeds do not develop normal foliose thalli in axenic cultures, but adopt an atypical morphology. Adding certain bacteria to the culture, however, can result in reversion to the normal morphology. The aim of the present study was to examine the effects of various algal-associated bacteria on the growth, morphology, and reproduction of the green alga Ulva fasciata. In axenic culture without added bacteria, U. fasciata grew into undifferentiated tissue initially and later developed into a tubular thallus. Of the 53 bacterial isolates we obtained from different species of Ulva and Gracilaria, only 5 were capable of inducing differentiation and subsequent growth in U. fasciata cultured in axenic conditions. One bacterial isolate (which we later identified as Marinomonas sp.) was more effective than the others in inducing morphogenesis and growth in $U$. fasciata. The physical association of bacterial cells with thalli was found to be crucial for the induction of $U$. fasciata foliose morphology, growth, and spore release. The culture filtrates from the 5 individual bacterial isolates and from a consortium of all 5 of them had less effect on morphogenesis and growth of $U$. fasciata than the bacteria themselves had, but more effect than the control (no bacteria added). Analysis of partial 16S rRNA gene sequences from all 5 isolates with morphogenesis-inducing ability led us to identify them as Marinomonas sp. and Bacillus spp. We found that the physical association of bacteria is essential for normal growth of the seaweed, suggesting a symbiotic interaction between seaweed and bacteria.
\end{abstract}

KEY WORDS: Bacterial isolates · Culture filtrate · Gracilaria spp. · Morphogenesis · Seaweed · Ulva fasciata Resale or republication not permitted without written consent of the publisher

\section{INTRODUCTION}

In the marine environment, bacteria are the most common colonizers on the surface of macroalgae (Armstrong et al. 2000). Seaweed-associated bacteria secrete biologically active, beneficial compounds that regulate the morphogenesis of marine organisms and help them survive under varied environmental conditions. The nature of the bacterial-seaweed interaction plays an important role and can influence the growth and various developmental stages (e.g. reproduction) of algae. Bacteria are generally assumed to benefit from soluble organic matter (as a source of energy) produced by host algae (Chandini et al. 2008). Bacterial biofilms of certain bacteria influence the settlement of zoospores of green alga of genus Enteromorpha (Patel et al. 2003). Spore release in the red algal genus Acrochaetium has also been reported to be enhanced by marine bacteria through $\mathrm{N}$-acyl homoserine lactone secretion (Weinberger et al. 2007). The plantlet growth-promoting nature of bacterial isolates associated with Laminaria japonica was reported by Dimitrieva et al. (2006).

Members of Ulvaceae lose their typical foliose thallus morphology when cultured axenically in defined synthetic media (Provasoli 1958, Provasoli \& Pintner 
1980). But their normal foliose morphology is restored when they are co-cultured with bacterial isolates capable of inducing differentiation. The aberrant morphology was successfully reversed to the foliose thallus following the inoculation of appropriate morphogenesisinducing bacterial isolates to the culture media (Nakanishi et al. 1996). Similar findings have been reported in studies with Ulva pertusa (Nakanishi et al. 1996), U. linza (Marshall et al. 2006), U. mutabilis (Wichard \& Oertel 2010), Enteromorpha linza (Fries 1975), E. compressa (Fries \& Aberg 1978), and Monostroma oxyspermum (Tatewaki et al. 1983, Matsuo et al. 2003). Direct physical contact between the algal and bacterial cells was shown to be a prerequisite for complete morphogenesis in $U$. pertusa (Nakanishi et al. 1999). Tatewaki et al. (1983) reported that the addition of culture filtrate of morphogenesis-inducing bacterial isolates was capable of providing the same effect as that caused by the addition of the bacterial culture itself. Similarly, Marshall et al. (2006) reported that culture filtrate restored the morphology of $U$. linza. It is now well established that cytokinin produced by marine bacteria is effective in regulating the morphogenesis pattern in seaweeds (Maruyama et al. 1986, 1988, Mooney \& Van 1986).

Bacterial genera such as Cytophaga, Flavobacterium, Vibrio, Pseudomonas, Halomonas, Escherichia and Bacillus have been implicated in promoting morphogenesis in Ulva pertusa (Nakanishi et al. 1999). Further, it has been shown that morphogenesis in green macroalgae (Ulvaceae and Monostromaceae) is induced by species of Cytophaga, Flavobacterium, Bacillus and other species belonging to the phyla Firmicutes and Bacteroidetes (Matsuo et al. 2005, Marshall et al. 2006). Along the Indian coast, the occurrence of the genera Bacillus, Vibrio, Micrococcus, Flavobacterium, and Cytophaga has been reported from the intertidal region, where seaweeds are one of the dominant benthic communities (Lakshmanaperumalsamy \& Purushothaman 1982). However, the mechanistic pathways associated with the induction of seaweed morphogenesis by associated bacterial flora have not yet been investigated in detail.

Ulva fasciata is one of the most common green algae and occurs almost every season on the Indian coast (Jha et al. 2009). The high protein content $(26 \%$ on a dry-weight basis) and nutritionally rich omega-3 fatty acids make this alga a potential source of food and feed (Oza \& Rao 1977, Kumari et al. 2010). Previous research on this alga has dealt with several fundamental aspects of biology, including phenology and ontogeny (Subbaramaiah 1970, Mantri et al. in press). Members of the genus Ulva are popular in Japanese and Korean cuisine and are commercially cultivated in these countries (Hiraoka \& Oka 2008). But the effects of associ- ated bacteria on this alga's growth, morphology and reproduction have not been examined. The present study describes the isolation and screening of 53 bacterial isolates obtained from Ulva and Gracilaria species and the bacteria's morphogenesis-inducing ability in $U$. fasciata grown in axenic culture. Five potential bacterial isolates having morphogenesis-inducing activity were further tested for their induction of growth and reproduction of $U$. fasciata vegetative tissue in axenic culture. Partial 16S rRNA gene sequences of the 5 strains with morphogenesis-inducing ability were used to determine their correct taxonomic identity and phylogenetic relationships. Further, the culture filtrates from these isolates were also tested for their ability to induce $U$. fasciata morphogenesis and subsequent growth.

\section{MATERIALS AND METHODS}

Isolation of bacteria. Fifty-three bacterial isolates were isolated from naturally collected thalli of Ulva fasciata, U. taeniata, U. lactuca, Gracilaria corticata, G. dura, and G. salicornia from the coast of Veraval $\left(20^{\circ} 54.87^{\prime} \mathrm{N}, 70^{\circ} 20.83^{\prime} \mathrm{E}\right)$, India (Table 1$)$. These species were found growing in association with each other in the intertidal area and thus selected for the present study. All the collections were made from pristine locations, away from anthropogenic activities, during the lowest tide of the chart datum in August 2009. The samples were immediately brought to the laboratory under cool conditions, and about $100 \mathrm{mg}$ tissue was washed gently 3 to 4 times in autoclaved seawater on a Bioclean bench (Sanyo). The cleaned algal tissue was inoculated onto marine agar medium (2216; HiMedia Laboratories) to allow growth of associated bacteria. The plates were then incubated at $37^{\circ} \mathrm{C}$ for $2 \mathrm{~d}$, and individual colonies were picked off and further streaked on marine agar plates in order to obtain single colonies. All bacterial isolates were further maintained on marine agar slants at $4^{\circ} \mathrm{C}$ and used for the subsequent experiments.

Table 1. Number of bacteria isolated from Ulva and Gracilaria spp. collected at Veraval, India, in August 2009

\begin{tabular}{|lcc|}
\hline Algal species & Abbreviation & $\begin{array}{c}\text { Number of } \\
\text { bacterial isolates }\end{array}$ \\
\hline Ulva fasciata & UF & 16 \\
U. lactuca & UL & 10 \\
U. taeniata & UT & 12 \\
Gracilaria dura & GD & 6 \\
G. corticata & GC & 5 \\
G. salicornia & GS & 4 \\
\hline
\end{tabular}


Preparation of unialgal samples and axenic tissue. Healthy vegetative thalli of Ulva fasciata collected from the intertidal area of the coast of Veraval were used for obtaining unialgal cultures. Algal fronds were cut into small pieces of about $1 \mathrm{~cm}^{2}$ and were thoroughly washed to remove adhering debris and other epiphytic contamination. The cut thallus pieces were further cultured in conical flasks with $100 \mathrm{ml}$ of enriched seawater medium (MP1) supplemented with $600 \mu \mathrm{leO}_{2}\left(1 \mathrm{mg} \mathrm{ml}{ }^{-1}\right.$ stock) to eliminate diatom growth. The flasks with algal pieces were then maintained in a Multi Thermo Incubator (MTI-202; Eyela) at $25 \pm 1^{\circ} \mathrm{C}$ temperature under daylight white fluorescent lamps at $15 \mu \mathrm{mol}$ photon $\mathrm{m}^{-2} \mathrm{~s}^{-1}$ irradiance with a 12:12 h light:dark photoperiod. After 2 to $3 \mathrm{~d}$ of acclimatization, fronds were given sequential treatment with different chemicals to obtain an axenic algal culture as described by Reddy et al. (2006). The axenicity of the algal culture was tested by incubating randomly selected algal tissue on Zobell agar medium over a week at $37 \pm 1^{\circ} \mathrm{C}$ in an incubator.

Effect of bacteria on algal morphogenesis and growth. Algal zoospores were induced and released from the axenic algal sample following the method of Mantri et al. (2010). A small aliquot of zoospore suspension with density $150 \times 10^{3}$ to $200 \times 10^{3}$ cells cm$^{-2}$ was dispensed into each well containing $5 \mathrm{ml}$ of enriched seawater medium in 12-well plates, which were then incubated in the Multi Thermo Incubator (MTI202, Eyela) at $25 \pm 1^{\circ} \mathrm{C}$ under daylight white fluorescent lamps at $15 \mu \mathrm{mol}$ photon $\mathrm{m}^{-2} \mathrm{~s}^{-1}$ irradiance with a 12:12 h light:dark photoperiod. After $24 \mathrm{~h}$ culture, an aliquot of $50 \mu$ l bacterial suspension from each of the 53 bacterial isolates was inoculated into the Ulva fasciata zoospore culture, and this was monitored for developmental morphology of spores. The control culture was maintained without addition of bacterial isolates. Cultures were grown for $15 \mathrm{~d}$ and the medium was replenished at $3 \mathrm{~d}$ intervals. The experiment was repeated 3 times. Visual interpretation of images taken at weekly intervals under an Olympus stereo zoom microscope (model SZ X16) was adopted as a nondestructive method to study the developmental morphogenesis of spores and their subsequent growth. Five putative morphogenesis-inducing bacteria (UF, GC, GS, UL24 and UL, named according to the algal species from which they were isolated, see Table 1) were identified for further study. A consortium of all 5 isolates was also subsequently assessed in triplicate for its effect on morphogenesis induction and growth. Further, culture filtrates $(0.22 \mu \mathrm{m}$, Millipore) obtained from the 5 individual isolates and from the consortium were separately incubated to study their effect on morphogenesis induction and growth. Growth of fronds was expressed as the relative increase in area. Micro- scopic features such as the appearance of cells on the surface, cell area, and presence or absence of marginal spines were also recorded under an Olympus microscope (model BX 60). ANOVA (1-way and 2-way) was used to analyze the morphogenesis-inducing bacteria's effects on algal growth, cell size, and zoospore induction, and significant differences were determined at $\mathrm{p} \times 0.05$. Dunnett's post hoc analysis was used to analyze bacteria-induced growth in U. fasciata.

To quantify the abundance of associated bacteria during algal growth, about $100 \mu \mathrm{l}$ of algal culture medium $\left(10^{-6}\right.$ dilution) was spread daily on marine agar medium (standard plate of $6 \mathrm{~cm}$ diameter) separately for all the isolates. The colony-forming units (CFUs) were counted manually after $24 \mathrm{~h}$ incubation at $37^{\circ} \mathrm{C}$.

Induction of algal spores by bacterial isolates. Disks of Ulva fasciata $\sim 5 \mathrm{~mm}^{2}$ were excised under axenic conditions from the algal stock culture. Ten disks $\sim 20 \mathrm{mg}$ were incubated in the multiwell plates containing $3 \mathrm{ml}$ of autoclaved enriched seawater medium and culture maintained in the Multi Thermo Incubator (MTI-202, Eyela) at $25 \pm 1^{\circ} \mathrm{C}$ under daylight white fluorescent lamps at $15 \mu \mathrm{mol}$ photon $\mathrm{m}^{-2} \mathrm{~s}^{-1}$ irradiance with a 12:12 h light:dark photoperiod. A small-sized sterile cover slip was put at the bottom of each well, and the zoospores that were released and that settled after $24 \mathrm{~h}$ were counted under an Olympus inverted microscope (model IX70). Data was expressed as the number of zoospores per gram of tissue. The bacterial cultures (UF, GC, GS, UL24, and UL) and their culture filtrates (0.22 $\mu \mathrm{m}$; Millipore) were inoculated onto separate plates while the control was maintained in the autoclaved medium at $25^{\circ} \mathrm{C}$. The experiment was repeated 3 times.

Scanning electron and epifluorescence microscopy. The algal fronds grown with the bacterial inoculation were gently washed 3 to 4 times with autoclaved seawater to remove loosely associated bacteria. Samples were fixed with $2.5 \%$ glutaraldehyde in sterile seawater overnight at $4{ }^{\circ} \mathrm{C}$. Then, they were gently washed in sterile seawater, and post-fixed in $2 \% \mathrm{OsO}_{4}$ at a 1:1 ratio (seawater:Milli-Q) for $2 \mathrm{~h}$. Thereafter, they were washed in sterile seawater and dehydrated in a graded ethanol series from $20 \%$ to $100 \%$. For scanning electron microscopy (LEO $1430 \mathrm{VP}$ ), specimens were coated with a gold alloy in a Sputter Coater (SC 7620). For epifluorescent microscopic observation of bacterial cells on the algal surface, bacterial DNA was stained with $5 \mu \mathrm{g} \mathrm{ml}^{-1}$ DAPI and observed using an FS 10 (fluorescein isothiocyanate) filter under a Carl Zeiss microscope (Zeiss Imager M1 microscope model AX10).

Genomic DNA isolation and amplification of $16 \mathrm{~S}$ rDNA gene sequence. Bacterial colonies were first incubated with lysozyme $\left(10 \mathrm{mg} \mathrm{ml}^{-1}\right)$ for $2 \mathrm{~h}$ at $37^{\circ} \mathrm{C}$. 
Afterwards genomic DNA was extracted using a cetyl trimethylammonium bromide (CTAB) buffer (CTAB 2\%, NaCl 1.4 mM, EDTA 50 mM, Tris 100 mM, polyvinyl pyrrolidone [PVP] 20\%) method (Chen \& Kuo 1993). Purification of genomic DNA was confirmed with $0.8 \%$ agarose gel electrophoresis. The universal forward bacterial primer rf (5'-AGA GTT TGA TCC TGG CTC AG-3'; Escherichia coli positions 8 to 27) and the reverse primer rr (5'-AAGGAGGTGATCCAG CCGCA-3'; E. coli positions 1541 to 1522) (Lapara et al. 2000) were used for PCR amplification of the partial 16S rRNA gene sequence. The reaction mixture contained $2.5 \mu \mathrm{l} 10 \times$ PCR buffer containing $\mathrm{MgCl}_{2}, 100 \mathrm{ng}$ of each forward and reverse primer, $25 \mathrm{mM}$ of each deoxynucleotide triphosphate (dATP, dCTP, dGTP, dTTP), 1 unit of Taq DNA polymerase, and $10 \mathrm{ng}$ of DNA template. The PCR protocol included a 5 min initial denaturation at $95^{\circ} \mathrm{C}$, followed by 30 cycles at $94^{\circ} \mathrm{C}$ for $40 \mathrm{~s}, 55^{\circ} \mathrm{C}$ for $40 \mathrm{~s}, 72^{\circ} \mathrm{C}$ for $2 \mathrm{~min}$, with a final cycle of $10 \mathrm{~min}$ at $72^{\circ} \mathrm{C}$, and incubation at $4^{\circ} \mathrm{C}$. Partial $16 \mathrm{~S}$ rDNA gene amplification products were put on $2 \%$ agarose gels and run at $50 \mathrm{~V}$ for $1 \mathrm{~h}$ at $25^{\circ} \mathrm{C}$ and visualized with a UV transilluminator. Bands were excised and purified using QIAquick PCR purification kit (Qiagen, no. 28104). Forward and reverse DNA sequencing reactions of PCR amplification were carried out with the rf and rr primers described above using a BDT v3.1 cycle sequencing kit on an ABI 3730xl Genetic Analyzer. Sequencing of isolates was done at Xcleris Laboratories, Ahmedabad (Gujarat, India). A search of the National Center for Biotechnology Information (NCBI) nucleotide database using the basic local alignment search tool (BLAST; http://blast.ncbi.nlm.nih.gov/ Blast.cgi) for similarity of $16 \mathrm{~S}$ rDNA gene sequences to isolated strains was made using the software MEGA-4 (Tamura et al. 2007). Partial sequences of 16S rDNA genes were generated from forward and reverse sequence data using Aligner software (DNA CodonCode). Partial 16S rRNA gene sequences were used to carry out BLAST searches in the NCBI GenBank database.

\section{RESULTS}

\section{Effect of bacteria on algal morphogenesis and growth}

A total of 53 bacterial isolates (35 from Ulva spp. and 18 from Gracilaria spp.) were isolated in the present study (Table 1). With no bacteria added, the axenic culture derived from $U$. fasciata zoospore germination was very aberrant when contrasted with the natural thallus (Fig. 1). Compact callus-like growth was ob-
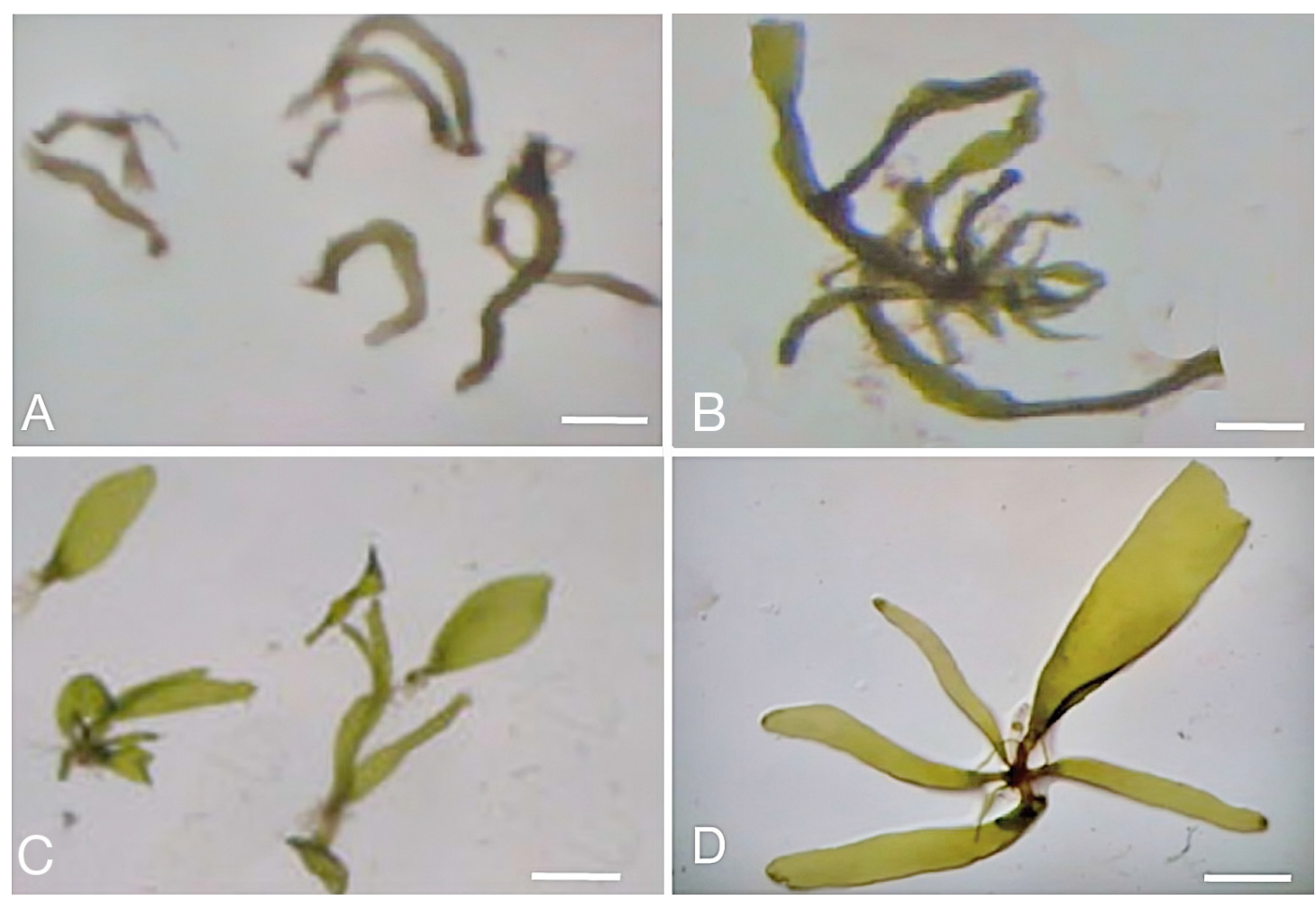

Fig. 1. Ulva fasciata. Morphogenesis of $U$. fasciata as axenic culture after (A) 4 wk and (B) 6 wk in the absence of morphogenesisinducing bacteria, and after (C) $4 \mathrm{wk}$ and (D) $6 \mathrm{wk}$ in the presence of morphogenesis-inducing bacteria. Scale bars $=1 \mathrm{~mm}$ 
served in culture after $2 \mathrm{wk}$, with no evidence of branching. Subsequent growth raised tubular creeping fronds after 4 wk of culture (Fig. 1A). Highly branched distinct tubular fronds were formed after subsequent culturing for 6 wk (Fig. 1B). In all these cases, the morphology of germlings was completely dissimilar to the natural thallus. Conversely, 5 putative morphogenesisinducing bacteria (UF, GC, GS, UL24, and UL) were able to induce considerable morphogenesis in axenic $U$. fasciata culture with similarity to the natural pattern of growth (Fig. 1C,D). The cell area of the mature thallus (after $4 \mathrm{wk}$ of culture) was $146 \mu^{2}$ in the control, while variable dimensions of $U$. fasciata cells in the surface view were recorded when grown with the 5 isolates as well as with their culture filtrates, and the inducing effect of the UF isolate was significant at $\mathrm{p} \leq 0.05$ (Fig. 2, Table 2). Individual cell sizes of $U$. fasciata were larger when morphogenesis took place in the presence of morphogenesis-inducing bacteria than

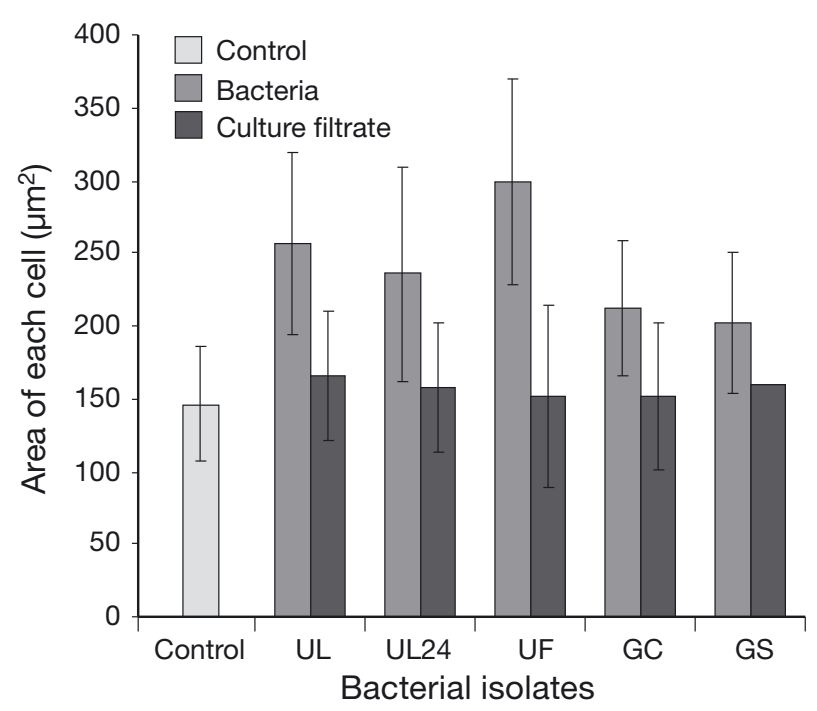

Fig. 2. Ulva fasciata. Effect of 5 different morphogenesisinducing bacterial isolates, their corresponding culture filtrates, and the control treatment on axenic $U$. fasciata cells ( $n=50$ cells). Effect is significant at $p \leq 0.05$. The effects of culture filtrates were not significant ( $p>0.05)$, in comparsion to bacterial isolates. Error bars represent SD when axenic cultures were allowed to develop alone (Fig. 3A,B). Out of all 5 isolates, the UF isolate induced spine development on the margins while others failed, in comparison with the culture filtrate and control (Fig. 3C,D). The arrangement of the cells showed a dif-
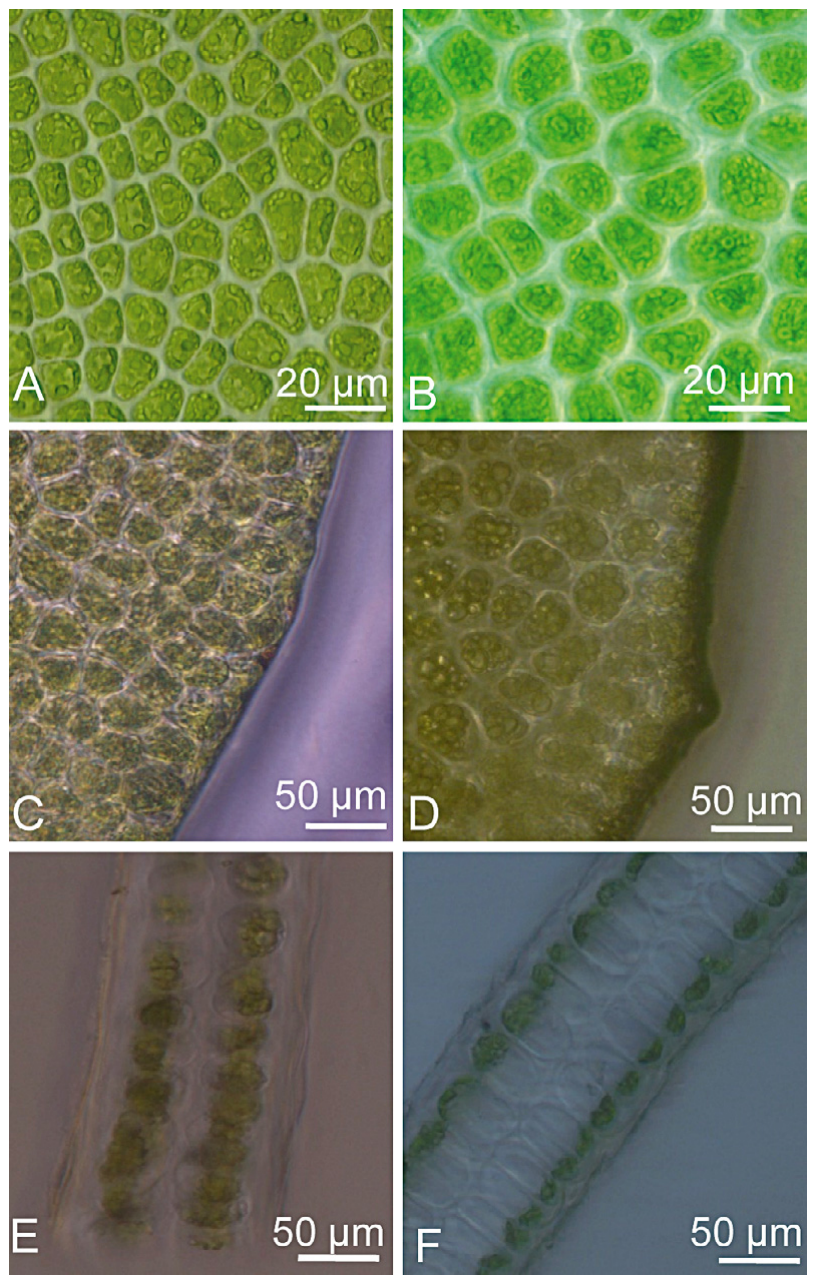

Fig. 3. Ulva fasciata. Morphogenesis of U. fasciata as axenic culture in the presence/absence of morphogenesis-inducing bacteria. (A) Cell size in the absence of bacteria, (B) cell size in the presence of bacteria, (C) absence of spine in the control, (D) presence of spine in the presence of bacteria, (E) atypical cell structure in the absence of bacteria, (F) wild-type cell structure in the presence of bacteria

Table 2. Ulva fasciata. Two-way ANOVA of the effects of different putative morphogenesis-inducing bacterial isolates on cell area, zoospore induction, and cell size in U. fasciata

\begin{tabular}{|c|c|c|c|c|c|c|c|c|c|c|c|c|c|c|c|}
\hline \multirow{2}{*}{ Source } & \multirow[b]{2}{*}{ df } & \multicolumn{2}{|c|}{ Cell area } & \multirow[b]{2}{*}{$F$} & \multirow[b]{2}{*}{$\mathrm{p}$} & \multirow{2}{*}{$\overline{\mathrm{df}}$} & \multicolumn{3}{|c|}{ - Zoospore induction } & \multirow[b]{2}{*}{$\mathrm{p}$} & \multirow[b]{2}{*}{ df } & \multirow[b]{2}{*}{ SS } & \multirow{2}{*}{$\begin{array}{l}\text { Cell size } \\
\text { MS }\end{array}$} & \multirow[b]{2}{*}{$F$} & \multirow[b]{2}{*}{$\mathrm{p}$} \\
\hline & & SS & MS & & & & SS & MS & $\mathrm{F}$ & & & & & & \\
\hline Isolates & 5 & 563.2 & 112.6 & 9.68 & 0.000 & 4 & $80 \times 10^{4}$ & $20 \times 10^{4}$ & 4.56 & 0.004 & 4 & $84 \times 10^{3}$ & $21 \times 10^{3}$ & 7.55 & 0.000 \\
\hline $\begin{array}{l}\text { Isolates } \times \\
\text { Culture filtrate }\end{array}$ & 2 & 894.5 & 447.2 & 38.4 & 0.000 & 2 & $35 \times 10^{5}$ & $17 \times 10^{5}$ & 39.1 & 0.000 & 2 & $10 \times 10^{5}$ & $53 \times 10^{4}$ & 190.7 & 0.000 \\
\hline Error & 46 & 535.1 & 11.6 & & & 38 & $17 \times 10^{5}$ & $44 \times 10^{3}$ & & & 623 & $17 \times 10^{5}$ & $28 \times 10^{2}$ & & \\
\hline Total & 53 & 1990 & & & & 44 & $60 \times 10^{5}$ & & & & 629 & $29 \times 10^{5}$ & & & \\
\hline
\end{tabular}




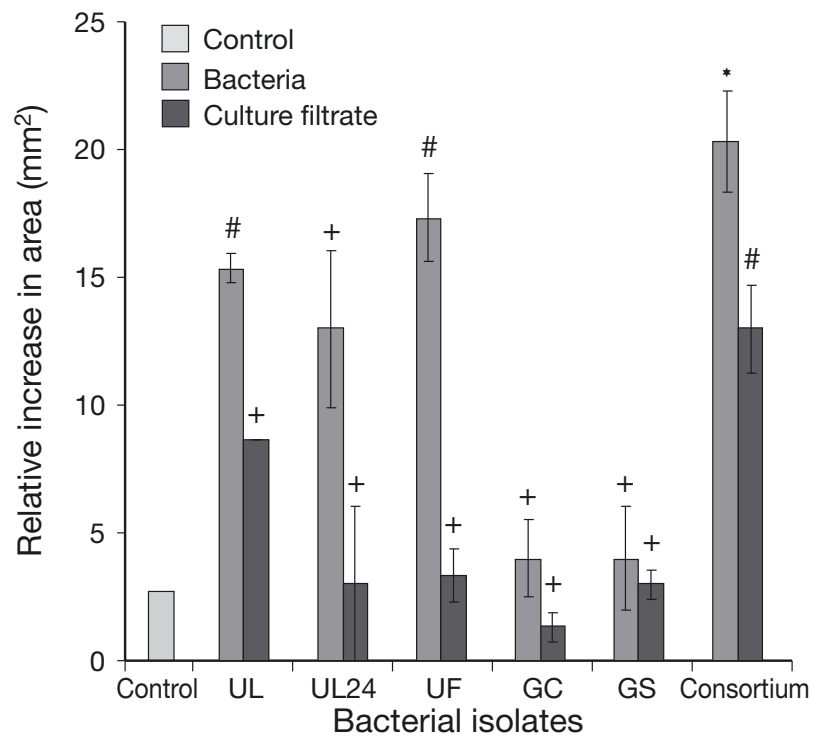

Fig. 4. Ulva fasciata. Effect of 5 different morphogenesisinducing bacteria and a consortium of all 5 of them, their corresponding culture filtrate, and a control treatment on $U$. fasciata thallus size. Dunnett's post hoc analysis: *represents the $99 \%$ confidence interval (CI), \# not significant at $99 \%$ CI, + represents the $95 \%$ CI. The effects of culture filtrates were not significant at $\mathrm{p}>0.05$, in comparison to bacterial isolates. Control: axenic $U$. fasciata culture; error bars: \pm SD

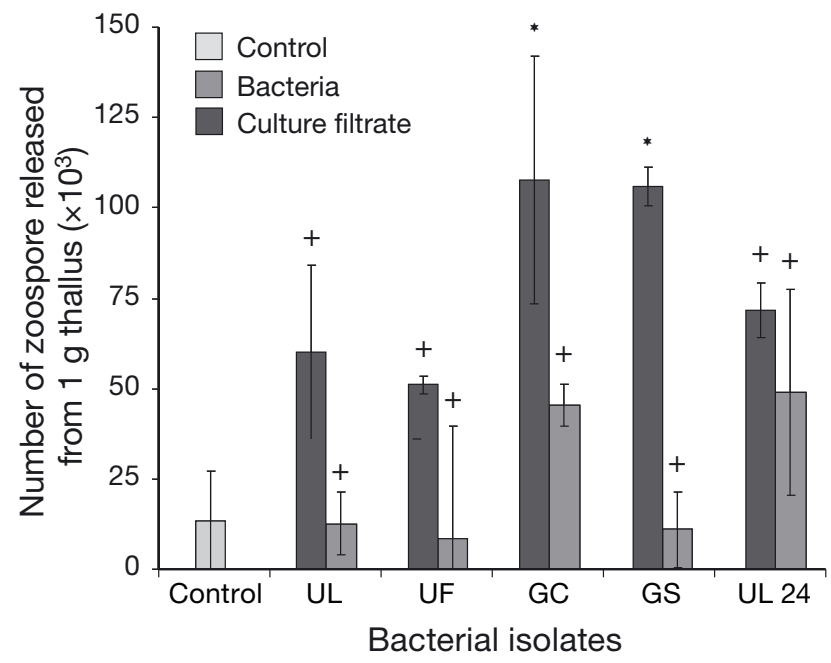

Fig. 5. Ulva fasciata. Effect of 5 different morphogenesisinducing bacteria, their corresponding culture filtrates, and the control treatment on spore induction in U. fasciata thalli. ANOVA: * represents the $95 \%$ confidence interval $(\mathrm{CI}),+$ not significant at $95 \%$ CI. The effects of culture filtrates were not significant at $\mathrm{p}>0.05$, in comparison to bacterial isolates.

Control: axenic $U$. fasciata culture; error bars: \pm SD

ferent pattern from the control in the cross-section view with the 5 putative morphogenesis-inducing bacteria (Fig. 3E,F). The increase in thallus area after $4 \mathrm{wk}$ was $2.67 \mathrm{~mm}^{2}$ in the control while a maximum increase of $20.33 \mathrm{~mm}^{2}$ was observed in the consortium (Fig. 4).
Minimum algal growth was recorded for bacterial isolates GC and GS $\left(4 \mathrm{~mm}^{2}\right)$. In the case of culture filtrates, a similar mode of relative increase in thallus area was recorded (Fig. 4). The induced morphogenetic growth was recorded in the following order: $\mathrm{UF}=\mathrm{UL}=\mathrm{UL} 24>\mathrm{GC}=\mathrm{GS}$. The consortium of all 5 isolates significantly promoted the growth of plantlets, as did UF, UL24, and UL individually ( $\mathrm{p} \leq 0.01$, Dunnett's post hoc analysis after 1-way ANOVA), while there was no significant difference in growth of plantlets grown with GS and GC at p $\leq 0.05$ (Table 2, Fig. 4). Isolates UF, GC, GS, and UL showed growth in the range of 1750 to $2750 \mathrm{CFU} \mathrm{ml}^{-1}$ at the end of $5 \mathrm{~d}$, whereas UL24 showed growth of ca. $4500 \mathrm{CFU} \mathrm{ml}^{-1}$.

\section{Effect of bacteria on algal spore induction}

GC and GS were the bacterial isolates that most prominently induced Ulva fasciata zoospore formation (Fig. 5). The strongest zoospore induction and highest spore release was induced by the GC isolate (107 700 zoospores $\mathrm{g}^{-1}$ fresh weight of thallus), while the lowest was induced by the UF isolate (51000 zoospores $\mathrm{g}^{-1}$ fresh weight of thallus). The culture filtrate of the UL24 and UF isolates induced the release of 49000 and 8600 zoospores $\mathrm{g}^{-1}$ fresh weight of thallus, respectively. Therefore, direct addition of bacterial cells was more effective for the induction of spores compared with the culture filtrate $(\mathrm{p} \leq 0.05,1$ - and 2-way ANOVA; Table 2). The induction and release of zoospores in the presence of the GC and GS isolates was statistically more significant in comparison with the other isolates (Fig. 5).

\section{Epifluorescence and scanning electron microscopy}

Under epifluorescence microscopy, the plantlet surface was brighter than bacteria due to a difference in focal length (Fig. 6A,B). Scanning electron microscopic observations confirmed that the bacterial cells were attached onto the algal surface. A particular pattern was not detected, and distribution was patchy on the algal surface (Fig. 6C-E).

\section{Characterization of bacterial isolates}

Based on the partial 16S rDNA gene sequences, the morphogenesis-inducing bacterial isolates UF, UL, UL24, GC, and GS were identified as Marinomonas sp. (GenBank accession no. GU592212), Bacillus flexus (GU592213), Bacillus sp. (GU592214), B. licheniformis strain RP-GC (GU723480), and B. licheniformis strain 


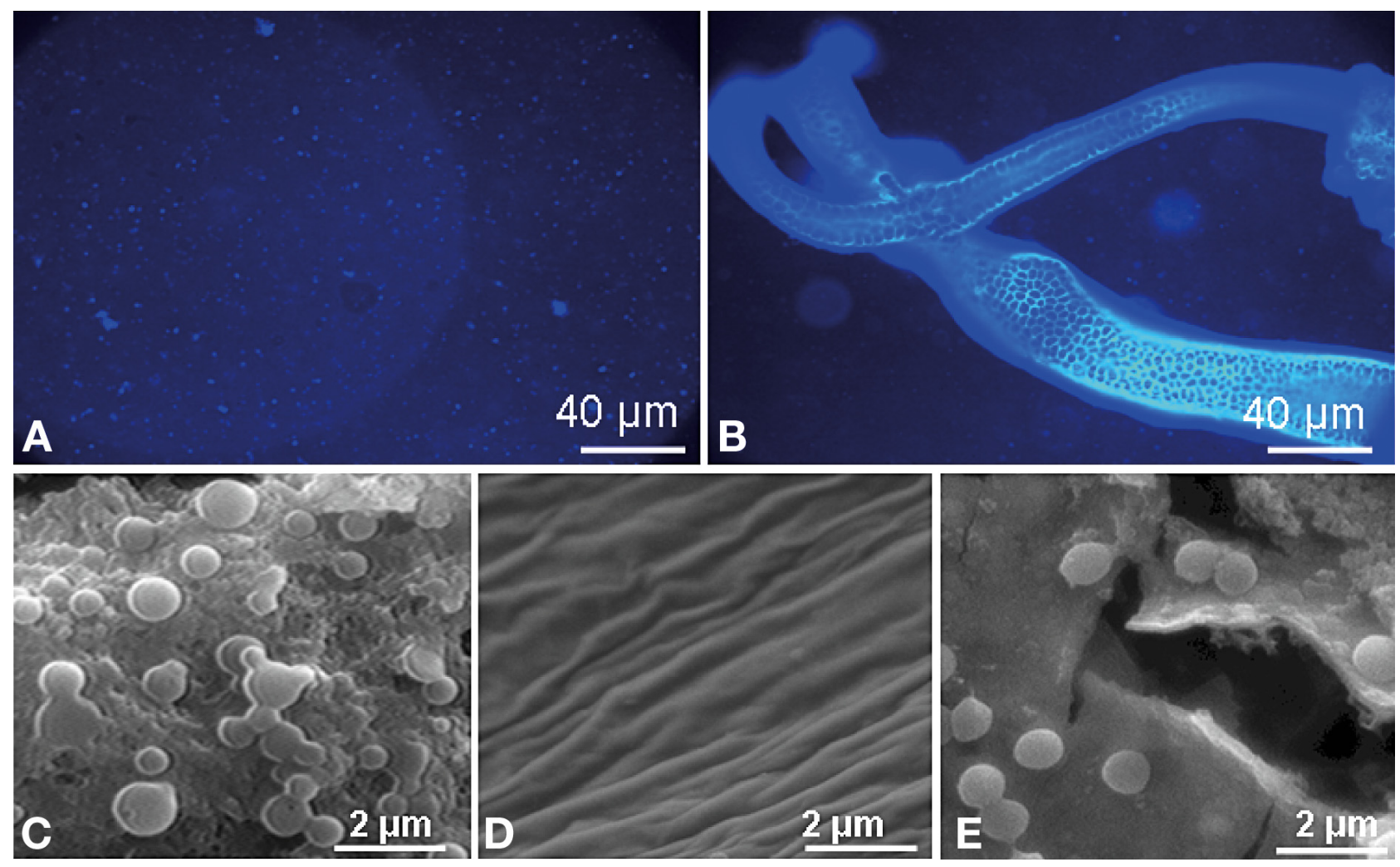

Fig. 6. Epifluorescence microscopy of (A) isolated bacterial colonies, (B) co-culture of both morphogenesis-inducing bacteria and Ulva fasciata. Scanning electron microscopy of (C) isolated Marinomonas sp. colonies, (D) axenically grown U. fasciata,

(E) U. fasciata co-cultured with morphogenesis-inducing bacteria

Table 3. Bacterial identification based on partial 16s rRNA gene sequences and the closest match in GenBank

\begin{tabular}{|lclcc|}
\hline Isolate ID & $\begin{array}{c}\text { GenBank } \\
\text { accession no. }\end{array}$ & $\begin{array}{c}\text { Closest matching strain in GenBank } \\
\text { (accession no.) }\end{array}$ & Phylum & $\begin{array}{c}\text { Sequence } \\
\text { similarity (\%) }\end{array}$ \\
\hline UF & GU592212 & Marinomonas sp. H1693 (GU183679) & Gammaproteobacteria \\
UL & GU592213 & Bacillus flexus strain Twd (FJ948078) & Firmicutes & 99 \\
GS & GU592215 & Bacillus sp. G1DM-53 (DQ416791) & Firmicutes & 99 \\
UL24 & GU592214 & Bacillus sp. L157 (AM913927) & Firmicutes & 97 \\
GC & GU723480 & Bacillus licheniformis strain JS-17 (GQ280087) & Firmicutes & 99 \\
\hline
\end{tabular}

RP-GS (GU592215), respectively. The isolates matched 97 to $99 \%$ with other sequences already present in GenBank (Table 3). Although both GC and GS were identified as Bacillus licheniformis, they were different based on the 16S rDNA gene sequence homology.

\section{DISCUSSION}

The findings in the present study revealed that the association of certain bacteria are essential for the normal growth of Ulva fasciata. This finding corroborates well with previous observations of axenic U. pertusa (Nakanishi et al. 1996), where direct bacterial attach- ment was required for algal growth, while other studies have shown that bacterial culture filtrate induced typical morphology in Enteromorpha sp. (Fries 1975), U. lactuca (Provasoli \& Pintner 1980), and U. linza (Marshall et al. 2006). However, very few studies were performed with isolates of bacteria that were phylogenetically well characterized. In the present study, isolates were identified by partial 16S rRNA gene sequences, and phylogenetic analysis showed that all 5 putative bacterial isolates were morphogenesisinducing bacterial isolates (Matsuo et al. 2003). Only 5 out of 53 bacterial isolates showed statistically significant induction of $U$. fasciata growth, morphology, and zoospore induction. The present study is the first report 
that morphogenesis-inducing bacteria are capable of inducing the differentiation of whole plantlets with respect to induction of spines on the surface, enlargement of cells, and regaining wild-type cell structure in U. fasciata. On the contrary, the culture filtrate of the 5 isolates and the control failed to induce the typical morphogenesis of $U$. fasciata. This suggests that physical contact between bacterial and host cells is necessary for the development of the particular cell shape, growth, and differentiation of $U$. fasciata. In case of the UL isolate and the consortium of all 5 bacterial isolates, the culture filtrate slightly helped in the development of morphology of the U. fasciata (Fig. 4), but it might have been less significant due to instability of the secreted substances or the signal. In contrast to the culture filtrate, tightly associated bacteria might be continuously secreting certain substances that enhance the growth and restore the typical morphology of U. fasciata.

It has also been reported that morphogenesis in macrophytic green algae from the families Ulvaceae and Monostromaceae are controlled by bacteria belonging to the genera Cytophaga, Pseudomonas, Staphylococcus, Vibrio, Bacillus, and Flavobacterium (Duan et al. 1995, Nakanishi et al. 1999, Matsuo et al. 2003, Marshall et al. 2006). The present study found that Marinomonas sp. and Bacillus spp. induced wildtype morphology and growth in Ulva fasciata. This is the first study where Marinomonas and Bacillus spp. are shown to be involved in the differentiation and growth of $U$. fasciata. In the present study, Bacillus spp. were also found to affect the morphology and growth of $U$. fasciata to a greater extent than that reported by Nakanishi et al. (1996) for U. pertusa. However, the effect of bacteria on the growth rate of macroalgae has not been well quantified. Subjective indications of induced growth and development have been reported for sporelings of $U$. pertusa, $U$. conglobata, and $U$. intestinalis when incubated with bacterial isolates of phylum Bacteroidetes (Matsuo et al. 2005, Marshall et al. 2006). The mechanism by which bacteria modulate the morphology of the plantlets is not yet well understood, although a number of hypotheses have been suggested. An endosymbiotic bacterium from the Agrobacterium-Rhizobium group, containing the nifH gene encoding for nitrogenase involved in nitrogen fixation, was isolated from rhizoids of the green alga Caulerpa taxifolia (Chisholm et al. 1996); it was suggested that this isolate might be important for nitrogen supply to the seaweed. A bacterium of the Roseobacter group was responsible for gall formation in the red alga Prionitis lanceolata due to overproduction of indole-3-acetic acid (Ashen \& Goff 2000). Phosphatesolubilizing activity of $B$. licheniformis has been reported to induce growth in mangrove plants (Rojas et al. 2001). It has also been suggested that secondary metabolites released by some epibiotic bacteria may prevent subsequent biofouling by other organisms (Holmstrom et al. 1996, Callow \& Callow 1998, Armstrong et al. 2001), thereby providing some protection to the host alga. In the present study, no correlation was found between the bacterial isolates that altered the differentiation of $U$. fasciata and those that enhanced spore induction. An interesting result is that those isolates that induced differentiation did not significantly induce spore production. Three isolates (UL, UF and UL24) accelerated differentiation in axenic $U$. fasciata. The consortium of all 5 putative morphogenesis-inducing isolates significantly induced algal differentiation (Table 2). The positive effect shown by the consortium suggested that normal morphology is not dependent on the presence of a single bacterium, but differentiation can be affected by a wide range of different bacteria. The results of the present study have further confirmed that the wide range of bacteria that induce algal differentiation presumably confers ecological flexibility to the alga so that it is not dependent on specific bacteria. There might be positive interactions between the morphogenesis-inducing bacterial isolates, but the mechanism of their interaction is still unclear. However, direct attachment of bacteria to the plantlet does appear to be essential, when the culturefiltrate results are considered. In addition, this is the first study providing evidence of the effect of bacterial isolates zoospore induction.

Further work on the mechanisms involved in these bacterial-seaweed interactions is in progress.

Acknowledgements. The financial support received from the Council of Scientific and Industrial Research (NWP 018; RSP 0016), New Delhi, is gratefully acknowledged. We also thank 4 anonymous reviewers for their critical comments which have improved the manuscript.

\section{LITERATURE CITED}

Armstrong E, Rogerson A, Leftley JW (2000) Utilisation of seaweed carbon by three surface-associated heterotrophic protists, Steromyxa ramosa, Nitzschia alba and Labyrinthula sp. Aquat Microb Ecol 21:49-57

Armstrong E, Tyan L, Boyd KG, Wright PC, Burgess JG (2001) The symbiotic role of marine microbes on living surfaces. Hydrobiologia 461:37-40

Ashen JB, Goff LJ (2000) Molecular and ecological evidence for species specificity and coevolution in a group of marine algal-bacterial symbioses. Appl Environ Microbiol 66: 3024-3030

Callow ME, Callow JA (1998) Enhance adhesion and chemoattraction of spore of the fouling alga Enteromorpha to some foul-release silicone elastomers. Biofouling 13:157-172

Chandini SK, Ganesan P, Suresh PV, Bhaskar N (2008) Seaweeds as source of nutritionally beneficial compounds - a review. J Food Sci Technol 45:1-13 
Chen W, Kuo T (1993) A simple and rapid method for the preparation of gram negative bacterial genomic DNA. Nucleic Acids Res 21:2260

Chisholm JRM, Dauga C, Ageron E, Grimont PAD, Jaubert JM (1996) 'Roots' in mixotrophic algae. Nature 381:382

Dimitrieva GY, Crawford RL, Yuksel GU (2006) The nature of plant growth-promoting effect of a pseudomonad associated with the marine algae Laminaria japonica and linked to catalase extraction. J Appl Microbiol 100:1159-1169

Duan D, Xu L, Fei X, Xu H (1995) Marine organism attached to seaweed surfaces in Jiaozhou Bay, China. World J Microbiol Biotechnol 11:351-352

Fries L (1975) Some observations on the morphology of Enteromorpha linza (L.) J. Ag. and Enteromorpha compressa (L.) Grev. in axenic culture. Bot Mar 18:251-253

Fries L, Aberg S (1978) Morphogenetic effects of phenylacetic acid and p-OH-phenylacetic acid on the green alga Enteromorpha compressa (L.) Grev. in axenic culture. Z Pflanzenphysiol 88:383-388

> Hiraoka M, Oka N (2008) Tank cultivation of Ulva prolifera in deep seawater using a new 'germling cluster' method. J Appl Phycol 20:97-102

> Holmstrom C, James S, Egan S, Kjelleberg S (1996) Inhibition of common fouling organisms by marine bacterial isolates with special reference to the role of pigmented bacteria. Biofouling 10:251-259

Jha B, Reddy CRK, Thakur MC, Rao MU (2009) Seaweeds of India: the diversity and distribution of seaweeds of Gujarat coast. Springer, Dordrecht

Kumari P, Kumar M, Gupta V, Reddy CRK, Jha B (2010) Tropical marine macroalgae as potential sources of nutritionally important PUFAs. Food Chem 120:749-757

Lakshmanaperumalsamy P, Purushothaman A (1982) Heterotrophic bacteria associated with seaweed. Proc Indian Acad Sci Plant Sci 91:487-493

Lapara TM, Nakatsu CH, Pantea L, Alleman JE (2000) Phylogenetic analysis of bacterial communities in mesophilic and thermophilic bioreactors treating pharmaceutical wastewater. Appl Environ Microbiol 66:3951-3959

Mantri VA, Singh RP, Bijo AJ, Kumari P, Reddy CRK, Jha B (2010) Differential response of varying salinity and temperature on zoospore induction, regeneration and daily growth rate in Ulva fasciata (Chlorophyta, Ulvales). J Appl Phycol doi:10.1007/s10811-010-9544-4

Marshall K, Joint I, Callow ME, Callow JA (2006) Effect of marine bacterial isolates on the growth and morphology of axenic plantlets of the green alga Ulva linza. Microb Ecol 52:302-310

Maruyama A, Maeda M, Simidu U (1986) Occurrence of plant hormone (cytokinin)-producing bacteria in the sea. J Appl Bacteriol 61:569-574

Maruyama A, Yamaguchi I, Maeda M, Simidu U (1988) Evidence of cytokinin production by a marine bacterium and its taxonomic characteristics. Can J Microbiol 34:829-833

Editorial responsibility: Hans Heinrich Janssen, Oldendorf/Luhe, Germany
Matsuo Y, Suzuli M, Kasai H, Shizuri Y, Harayama S (2003) Isolation and phylogenetic characterization of bacteria capable of inducing differentiation in the green alga Monostroma oxyspermum. Environ Microbiol 5:25-35

Matsuo Y, Imagawa H, Nishizawa M, Shizuri Y (2005) Isolation of an algal morphogenesis inducer from a marine bacterium. Science 307:1598

Mooney PA, Van SJ (1986) Algae and cytokinins. J Plant Physiol 123:1-21

Nakanishi K, Nishijima M, Nishimura M, Kuwano K, Saga N (1996) Bacteria that induce morphogenesis in Ulva pertusa (Chlorophyceae) grown under axenic conditions. J Phycol 32:479-482

Nakanishi K, Nishijima M, Nomoto AM, Yamazaki A, Saga N (1999) Requisite morphologic interaction for attachment between Ulva pertusa (Chlorophyta) and symbiotic bacteria. Mar Biotechnol 1:107-111

Oza RM, Rao PS (1977) Effect of different culture media on growth and sporulation of laboratory raised germlings of Ulva fasciata Delile. Bot Mar 20:427-431

Patel P, Callow ME, Joint I, Callow JA (2003) Specificity in the settlement-modifying response of bacterial biofilms towards zoospores of the marine alga Enteromorpha. Environ Microbiol 5:338-349

> Provasoli L (1958) Effect of plant hormones on Ulva. Biol Bull (Woods Hole) 114:375-384

Provasoli L, Pintner IJ (1980) Bacteria induced polymorphism in an axenic laboratory strain of Ulva lactuca (Chlorophyceae). J Phycol 32:479-482

Reddy CRK, Dipakkore S, Rajakrishan KG, Jha B, Cheney DP, Fujita Y (2006) An improved enzyme preparation for rapid mass production of protoplasts as seed stock for aquaculture of macrophytic marine green algae. Aquaculture 260: 290-297

Rojas A, Holguin G, Glick BR, Bashan V (2001) Synergism between Phyllobacterium sp. ( $\mathrm{N}_{2}$-fixer) and Bacillus licheniformis (P-solubilizer), both from a semiarid mangrove rhizosphere. FEMS Microbiol Ecol 35:181-187

- Subbaramaiah K (1970) Growth and reproduction of Ulva fasciata Delile in nature and in culture. Bot Mar 13:25-27

> Tamura K, Dudley J, Nei M, Kumar S (2007) MEGA4: Molecular Evolutionary Genetics Analysis (MEGA) software version 4.0. Mol Biol Evol 24:1596-1599

Tatewaki M, Provasoli L, Pintner IJ (1983) Morphologenesis of Monostroma oxyspermum (Kutz) Doty (Chlorophyceae) in axenic culture, especially in bialgal culture. J Phycol 19: 409-416

- Weinberger F, Beltran J, Correa JA, Lion U and others (2007) Spore release in Acrochaetium sp. (Rhodophyta) is bacterially controlled. J Phycol 43:235-241

Wichard T, Oertel W (2010) Gametogenesis and gamete release of Ulva mutabilis and Ulva lactuca (Chlorophyta): regulatory effects and chemical characterization of the 'swarming inhibitor'. J Phycol 46:248-259

Submitted: June 29, 2010; Accepted: December 8, 2010 Proofs received from author(s): February 18, 2011 